\title{
Response of a natural phytoplankton assemblage to pulsed supply of phosphorus in semicontinuous cultures
}

\author{
M. Ghosh ${ }^{1}$ \\ K.V. Rajendra Prasad 1 \\ S.K. Mehtal \\ J.P. Gaur ${ }^{1.2}$
}

Keywords : phytoplankton, phosphorus, community structure, blue-green algae, diatoms, semicontinuous culture.

A natural phytoplankton assemblage from a pond was grown in semicontinuous cultures receiving phosphorus $(\mathrm{P})$ pulses once every 2 or 6 days. The study shows that the structure of phytoplankton assemblage depends on the mode of P supply. Biomass, expressed as total biovolume, was greatest in cultures receiving $P$ pulse once every 2 days. While the total amount of $P$ administered to both pulsed cultures remained similar, differences in structure of the phytoplankton assemblage were observed during the 4 weeks experimental period. The small sized Navicula cryptocephala became dominant in cultures which did not receive $P$ pulses. Therefore, this species seems to be «affinity specialist» well-adapted to a low P concentration. The replacement of the dominant cyanobacterium Gomphosphaeria aponina by the diatoms Navicula cryptocephala and Synedra ulna in the control and P-pulsed cultures might be due to another factor. The large sized Phormidium mucosum and Hormidium sp. were favoured in cultures pulsed with $\mathrm{P}$ at the lowest frequency, which seems to be due mainly to their larger $\mathrm{P}$ accumulation capacity. Synedra ulna was favoured to the same extent under the 2 and 6-day pulse periods.

\section{Réponse d'une communauté de phytoplancton soumise à des apports de phosphore en culture semi-continue}

Mots-clés : phytoplancton, phosphore, structure de communauté, algues, diatomées, culture semi-continue.

Une communauté phytoplanctonique d'un étang a été cultivée en culture semi-continue avec des apports de phosphore tous les 2 ou 6 jours. L'étude montre que la structure de la communauté phytoplanctonique dépend de la fréquence des apports de P. La biomasse, exprimée en biovolume total, était maximale dans les cultures enrichies tous les 2 jours. Bien que la quantité totale de $P$ ajoutée aux 2 cultures soit similaire, des différences dans la composition de phytoplancton étaient observées au cours des 4 semaines d'expérimentation. La petite espèce Navicula cryptocephala devenait dominante dans les cultures non enrichies en $\mathrm{P}$. Cependant, cette espèce semble être une «affinity specialist» bien adaptée aux faibles concentrations en P.'

Le remplacement de la cyanobactérie dominante Gomphospharium aponina par les diatomées Navicula cryptocephala et Synedra ulna dans les cultures témoins et enrichies en $\mathrm{P}$ peut être dû à un autre facteur. Les espèces de grande taille Phormidium mucosum et Hormidium sp. étaient favorisées dans les cultures avec les apports de $\mathrm{P}$ les moins fréquents ; ce qui semble lié à leur possibilité de stockage de cet élément. Synedra ulna répondait de la même façon quelle que soit la fréquence des apports.

\section{Introduction}

Phosphorus has been identified as the nutrient that most often limits phytoplankton growth in freshwater

\footnotetext{
1. Laboratory of Algal Biology, Department of Botany, Banaras Hindu University, Varanasi 221005 , India.

2. Correspondent author : E-mail: jpgaur@banaras.ernet.in
}

(Hecky \& Kilham 1988), while nitrogen, carbon, silica, trace elements and light have been found limiting in some aquatic systems (Reynolds 1984). Algal biomass and total $P$ concentration in lakes are related to each other (Thompson \& Rhee 1994). Laboratory bioassay and whole-lake fertilization experiments have demonstrated that increased concentration of $P$ often leads to formation of algal blooms. Increased $P$ supply in lakes also alters composition of phytoplankton with 
appearance of nuisance species, particularly cyanobacteria. Nutrient uptake and growth kinetics of several phytoplankton species have been largely studied in laboratory (e.g., Rhee 1978, Rhee \& Gotham 1980, Olsen 1988, Spijkerman \& Coesel 1996). These investigations revealed variability in abilities of phytoplankton species to utilize nutrients for growth. This variability has been considered as one of the explanations for the paradox of plankton, i.e., coexistence of several species (see Tilman 1982). Among phytoplankton species, good competitors for one resource are poor competitors for another, and thus several species are able to coexist in natural waters (Hecky \& Kilham 1988).

Phytoplankton species are exposed to environmental heterogeneity due to temporal and spatial fluctuations in supply of nutrients and other resources. Variability in distribution of nutrients is due to excretions of nutrients by zooplankton and fish, and episodic events such as storms, seiches and wind mixing or seasonal turnover (Turpin 1988). Continuous cultures of phytoplankton species have shown abilities of some species to efficiently use pulses of nutrients (Sakshaug \& Olsen 1986, Suttle et al., 1987, Olsen 1989). A relatively larger number of species are able to coexist under fluctuating supply of nutrients than under constant supply (Turpin 1988). The mode of supply of a nutrient may determine species composition of a natural phytoplanktonic assemblage. For instance, Staurastrum luetkemuellerii outcompeted Microcystis aeruginosa in a chemostat with a constant $P$ supply, whereas the latter species became dominant when $P$ was supplied in pulses (Sakshaug \& Olsen 1986). In continuous cultures, desmid species could outcompete each other depending on the mode of $P$ supply (Spijkerman \& Coesel 1996). Under severe $P$ limitation, Cosmarium abbreviatum outcompeted Staurastrum pingue. The latter species predominated under pulsed supply of P. Much information has accumulated regarding the impact of homogeneous supply of $\mathrm{P}$ on the structure of phytoplanktonic assemblages of lakes and ponds (Tilman et al. 1986, Sommer 1983, 1993).

The present work was taken up as (i) information on the effect of nutrient pulses on freshwater phytoplankton is scarce (Sommer 1985, Suttle et al. 1987), and (ii) tropical and subtropical phytoplankton have not been investigated in this context up to now.

\section{Materials and methods}

A phytoplankton assemblage was collected in September 1996 from a middle-sized mesotrophic pond (100 x $60 \mathrm{~m}$; mean depth $3 \mathrm{~m}$ ) located at Kandwa, Varanasi, India. $\left(25^{\circ} 18^{\prime} \mathrm{N}, 83^{\circ} 01^{\prime} \mathrm{E} ; 80 \mathrm{~m}\right.$ above the m.s.l.). The whole pond area is lined with concrete. The main source of water is rainwater and runoff from surrounding areas. The pond is in the vicinity of human settlements and is used for various domestic and agricultural purposes. About 121 water sample were collected in large polyethylene containers from various points of the pond with a $2.5 \mathrm{~m}$ long weighted rubber sampling tube as per Lund \& Talling (1957). Temperature was measured in the field with a thermometer. The samples were pooled and transported to the laboratory. Two litres of water were filtered through a $0.45 \mu \mathrm{m}$ membrane filter and analyzed for nutrients like dissolved silica, $\mathrm{NO}_{3}-\mathrm{N}, \mathrm{NH}_{4}-\mathrm{N}$, soluble reactive phosphorus (SRP) and total phosphorus (TP) within five hours after collection according to Wetzel \& Likens (1979).

The experiment was set up with filtered pond water. The initial volume of pond water in each flask was $100 \mathrm{ml}$. Two replicates were considered for the control (no addition of P) and P-pulsed flasks. The natural phytoplankton assemblage was concentrated by centrifugation and inoculated into culture flasks to give an initial cell density of about $2 \times 10^{3}$ cells $\mathrm{ml}^{-1}$. In order to carry out dilution of cultures, the remaining sample was filtered through a $0.45 \mu \mathrm{m}$ membrane filter, autoclaved and stored in the dark in sterilized container pre-washed with $0.2 \mathrm{~N} \mathrm{HCl}$ (Lovstad 1984).

$P$ was added manually from a stock solution of $\mathrm{K}_{2} \mathrm{HPO}_{4} .20 \mu \mathrm{g} \mathrm{P} \mathrm{l}^{-1}$ was added to flasks receiving pulses once every 2 days. $60 \mu \mathrm{g} \mathrm{P} ~^{-1}$ was added to flasks receiving pulses once every 6 days. This resulted in the addition of $300 \mu \mathrm{g} \mathrm{P} \mathrm{l}^{-1}$ in both P-supplemented cultures during the course of the experiment. The culture flasks were incubated at $25^{\circ} \mathrm{C}$ receiving $200 \mu \mathrm{E}$ $\mathrm{m}^{-2} \mathrm{~s}^{-1}$ PAR at the surface of vessels in a $10: 14 \mathrm{LD}$ cycle. The culture flasks were manually shaken several times a day. The positions of flasks were regularly changed for proper distribution of light. Every 2 days, all flasks were mixed and diluted by withdrawing $50 \mathrm{ml}$ of the sample and replacing it by the same volume of filtered pond water. Dilution rate (D) was 0.35 $\mathrm{d}^{-1}(\mathrm{D}=-\ln \mathrm{f} / 2$, where $\mathrm{f}$ is the fraction of original volume diluted; Suttle et al. 1987). One half of each water sample withdrawn from the control and the treatment flasks was filtered through a $0.45 \mu \mathrm{m}$ membrane filter and SRP analyzed colorimetrically according to Murphy \& Riley (1982). The other half of each sample was used to study the phytoplankton distribution in the control and P-enriched flasks.

Algal species were identified and counted with a Spencer's brightline haemocytometer. Biomass of each species was determined by transforming cell count data to total biovolume. Cell biovolume was based on 


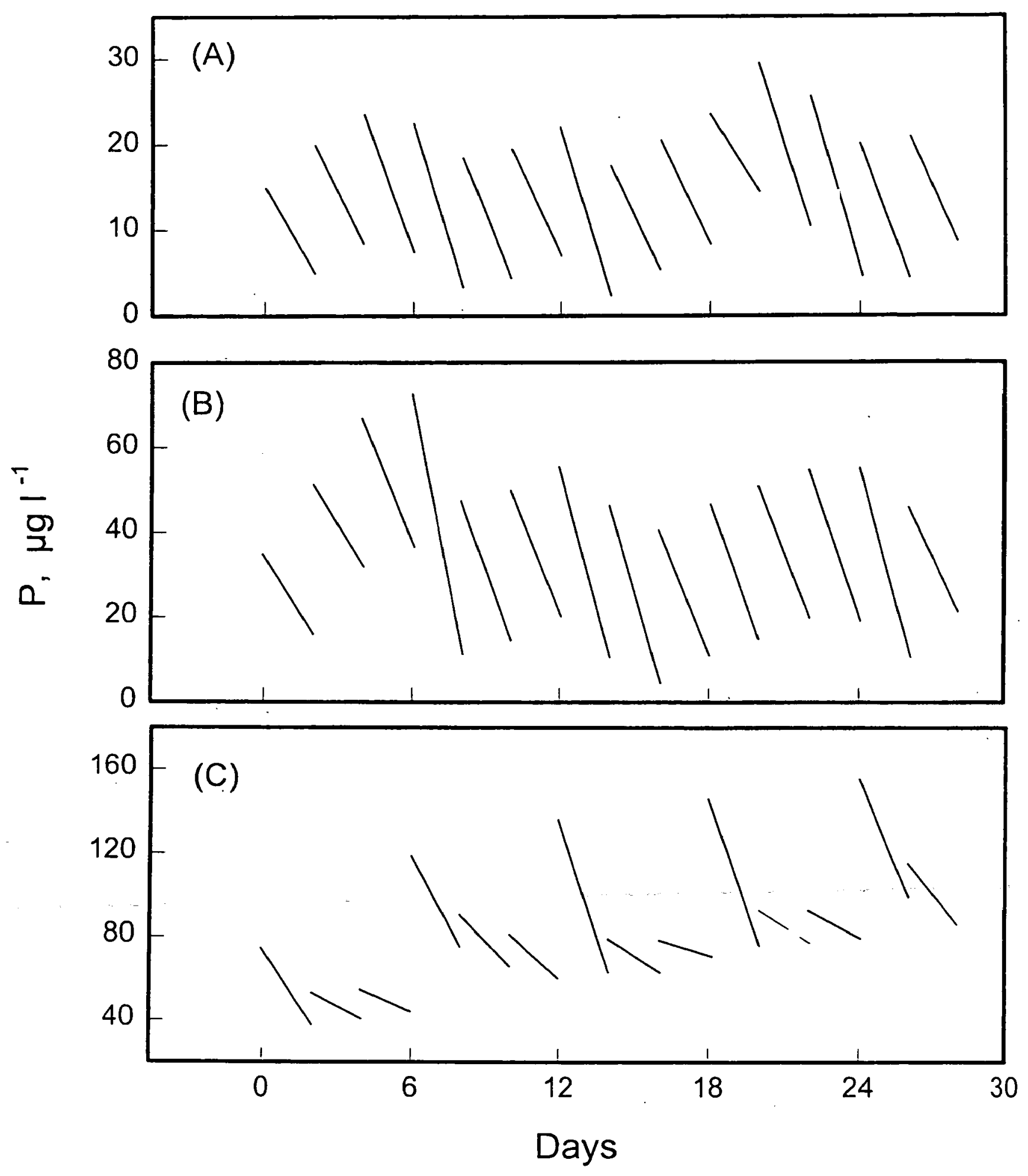

Fig. 1. Changes in the ambient phosphorus (P) concentration in (A) control flasks (no enrichment) ; (B) flasks re-

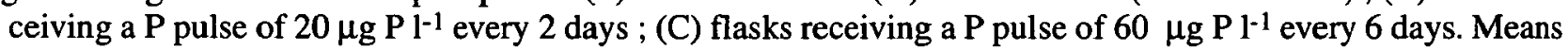
of 2 replicates.

Fig. 1. Variations de la concentration en $P$ : (A) dans les cultures témoins : (B) dans les cultures recevant des apports de $20 \mu \mathrm{g} \mathrm{P}^{-1}$ tous les 2 jours ; (C) dans les cultures recevant des apports de $60 \mu \mathrm{g} \mathrm{P}^{-1}$ tous les 6 jours. Moyennes des 2 «replicats». 


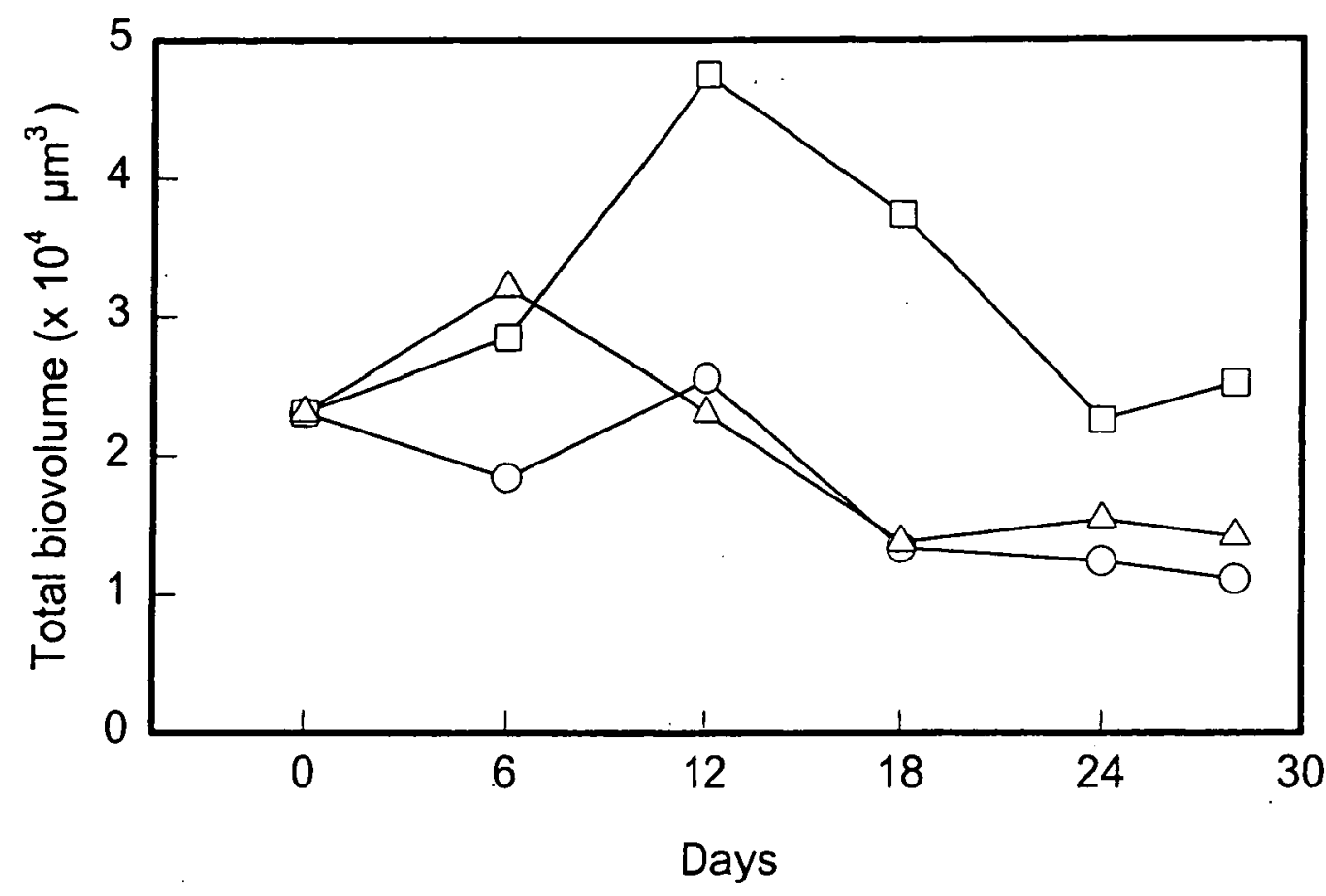

Fig. 2. Total phytoplankton biovolume in control flasks (open circles), in the flasks receiving a $\mathrm{P}$ pulse of $20 \mu \mathrm{g} \mathrm{l}^{-1}$ every 2 days (open squares) and in the flasks receiving a $P$ pulse of $60 \mathrm{\mu gl}^{-1}$ every 6 days (open triangles).

Fig. 2. Biovolume total du phytoplancton dans les bouteilles de contrôle (cercles), dans les cultures recevant un apport de $20 \mu \mathrm{g} P$ tous les 2 jours (carrés) et dans les bouteilles recevant un apport de $60 \mu \mathrm{gl}^{-1}$ de $\mathrm{P}$ tous les 6 jours (triangles).

geometrical approximations according to Clarke et al. (1987). For colonial species, the volume of a single cell was multiplied by the cell density to derive total algal biovolume. For the filamentous species, the cell number was multiplied by the volume of a single cell.

\section{Results}

Various physico-chemical characteristics of pond water at the beginning of the experiment are shown in Table 1. Pond water was mildly alkaline. Silicate concentration was high $\left(10.5 \mathrm{mg}^{-1}\right)$. Low level of SRP was evident. Total inorganic $\mathrm{N}$ : total inorganic $\mathrm{P}$ ratio in the pond water was around 17.0 (atoms). Nitrite-nitrogen was below the limit of detection, i.e., $<0.01 \mathrm{mg} \mathrm{l}^{-1}$.

A steady decline in the concentration of SRP was apparent in the control and in the P-pulsed cultures (Fig. 1). $P$ depletion was rapid in the cultures pulsed with $P$ every 2 days. The depletion of $P$ showed a consistent pattern under both the regimes of $P$ supply throughout the experiment. At the beginning, the total algal biovolume was the highest in the semicontinuous culture pulsed with $P$ every 6 days (Fig. 2). A decrease was evident after the 6 th day (i.e. the second pulse). However, the highest biomass was gradually reached in the culture pulsed with $\mathbf{P}$ on alternate days.
Table 1. Physico-chemical characteristics of pond water.

Tableau 1. Caractéristiques physico-chimiques de l'eau de l'étang.

\begin{tabular}{llc}
\hline Variable & Unit & $\begin{array}{c}\text { Mean } \\
(\mathbf{n}=3)\end{array}$ \\
\hline Temperature & ${ }^{\circ} \mathrm{C}$ & 24 \\
$\mathrm{pH}$ & - & 7.7 \\
Dissolved silica & $\mathrm{mg} \mathrm{l}^{-1}$ & 10.5 \\
$\mathrm{NO}_{3}-\mathrm{N}$ & $\mu \mathrm{g} \mathrm{l}^{-1}$ & 40 \\
$\mathrm{NH}_{4}-\mathrm{N}$ & $\mu \mathrm{g} \mathrm{l}^{-1}$ & 75 \\
$\mathrm{SRP}$ & $\mu \mathrm{g} \mathrm{l}^{-1}$ & 15 \\
$\mathrm{TP}$ & $\mu \mathrm{g} \mathrm{l}^{-1}$ & 38.7 \\
\hline
\end{tabular}

The change in community structure over time was followed in the control and in the P-enriched semicontinuous cultures of the natural phytoplankton assemblage (Figs. 3a, b, c). During the course of the experiment, a few species disappeared whereas populations of other species varied depending upon the mode of treatment. At the beginning of the experiment, the cyanobacterium Gomphosphaeria aponina was dominant, representing more than $80 \%$ of the total biovolume. In the course of the experiment, its populations declined in the control and P-pulsed cultures. Pediastrum duplex survived only in the control flasks and was not 

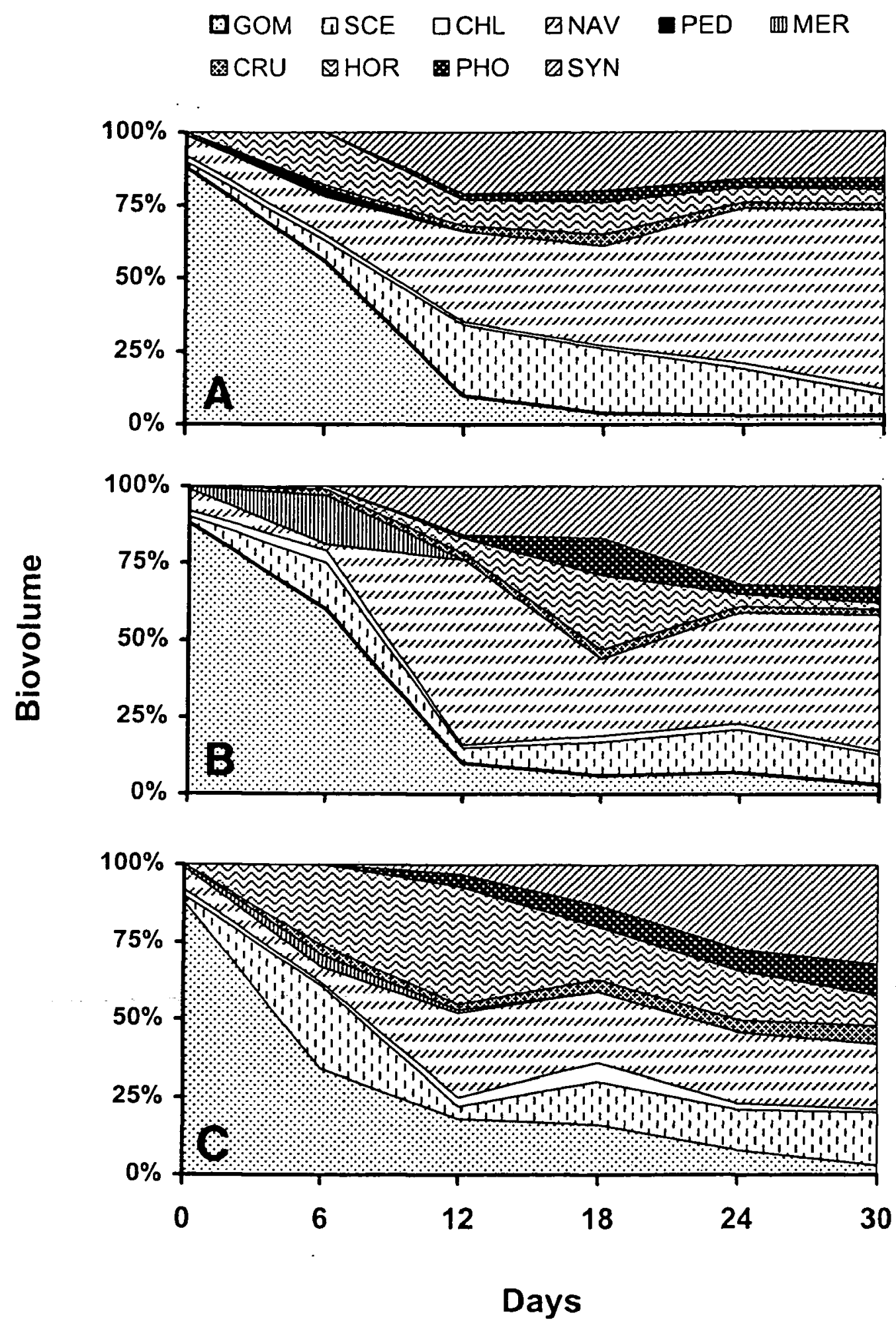

Fig. 3. Relative abundance of phytoplankton species in semicontinuous cultures: (A) control, (B) Pulsed with P every 2 days, and (C) pulsed with P every 6 days. Values plotted are means of two replicates. Species codes are as follows : SYN - Synedra ulna, PHO - Phormidium sp., HOR - Hormidium sp., CRU - Crucigenia sp., NAV - Navicula cryptocephala, CHL - Chlorella vulgaris, SCE - Scenedesmus quadricauda, GOM - Gomphosphaeria aponina, MER - Merismopedia tenuissima, PED - Pediastrum duplex.

Fig. 3. Abondance relative des espèces de phytoplancton en cultures semi-continues: $\mathrm{A}$ : témoins ; B : apports en $P$ tous les 2 jours ; $C$ : apports en $P$ tous les 6 jours. Les valeurs du graphique sont les moyennes de deux «replicats». Codes espèces : SYN - $S y$ nedra ulna, PHO - Phormidium sp., HOR - Hormidium sp., CRU - Crucigenia sp., NAV - Navicula cryptocephala, CHL - Chlorella vulgaris, SCE - Scenedesmus quadricauda, GOM - Gomphosphaeria aponina, MER - Merismopedia tenuissima, PED - Pediastrum duplex. 
seen after the 12th day. Merismopedia tenuissima also disappeared in the control and two treatment flasks. In the control, the diatom Navicula cryptocephala increased in abundance with time, with a maximum biovolume at the end of the experiment. Chlorella vulgaris, Scenedesmus quadricauda and Crucigenia sp. did not respond to $\mathrm{P}$ pulses. Their contribution to total biovolume did not change much during the experimental period. A number of species responded positively to $P$ enrichment. Synedra ulna responded similarly under two regimes of $\mathrm{P}$ addition. However, Phormidium $\mathrm{sp}$. and Hormidium sp. grew better in cultures least often pulsed with $P$. The pulsed addition of $P$ did not cause oscillation of number of any of the phytoplankton species.

\section{Discussion}

The structure of phytoplanktonic assemblage showed a strong dependence on the mode of P supply. Some algal species responded positively to $P$ addition because they were P limited. While Navicula cryptocephala was dominant in the control, its contribution to the total biovolume of the community became smaller in P-supplemented cultures. $N$. cryptocephala appears to be an «affinity specialist» (see Sommer 1984), with a low half saturation constant for its growth, as it was favoured by a low and constant supply of $P$ in the control. Blue-green algae are poor competitors for $\mathbf{P}$ and enhanced supply of $P$ increases their abundance (Tilman 1982, Smith 1983, Tilman et al. 1986). But the Gomphosphaeria aponina population decreased in the control and P-enriched flasks. The growth of this cyanobacterium was obviously limited by some other resource. Similar was the case with Merismopedia tenuissima. Population of none of the algae oscillated in P-supplemented cultures. These results point towards absence of «velocity specialists» (high maximum rate of nutrient uptake matching with rapid growth rate; Sommer 1984).

Phormidium mucosum and Hormidium sp. were most favoured in cultures with the lowest frequency of $\mathrm{P}$ pulsing. They seem to be «storage specialists» (high maximum rate of nutrient uptake but lower growth rate ; Sommer 1984) being able to accumulate high concentrations of $\mathrm{P}$ in cell for subsequent utilization for growth. This viewpoint agrees with Schindler et al. (1979) and Lean \& White (1983) who found a larger proportion of $\mathrm{P}$ in large sized phytoplankton species with increase in concentration of $P$ in water. In a culture least frequently pulsed with high concentration of a limiting nutrient, larger phytoplankton species grew better than their smaller counterparts as they may be able to sustain elevated uptake rate of the limiting nutrients for a longer period of time (Suttle et al. 1987). However, it should be kept in view that larger algae generally have a higher minimum cell quota of a limiting nutrient than the smaller ones (Shuter 1978). Increasing abundance of large algae in semicontinuous cultures receiving pulsed supply of $P$ every 2 or 6 days is in agreement with Turpin \& Harrison (1980), Suttle et al. (1987) and Stolte \& Riegman (1996).

The cultures pulsed with P every 2 or 6 days showed an increase in abundance of Synedra ulna. It seems that this diatom is a good competitor for $\mathrm{P}$ under various frequencies of $\mathrm{P}$ pulses. In several $\mathrm{P}$-competition experiments with multispecies cultures, Synedra spp. were able to outcompete many algae under various experimental conditions (Sommer 1983, Smith \& Kalff 1983, Tilman \& Kiesling 1984).

In conclusion, $\mathrm{P}$ pulses control the structure and $\mathrm{dy}$ namics of natural phytoplankton assemblages. Measurement of growth kinetics and nutrient uptake characteristics of various species is needed for more meaningful interpretation of such data. Nevertheless, a simple device such as the semicontinuous culture can be extremely useful to study the impact of nutrient pulses on a natural phytoplankton assemblage. Such an approach may also allow identification of species preferring various modes of supply of limiting nutrients.

\section{Acknowledgements}

The Department of Science and Technology and Council of Scientific and Industrial Research, New Delhi, provided financial support for the study. We thank the Head, Department of Botany, B.H.U. for other facilities. Mr. Ranganath Singh typed this manuscript. Thanks to an anonymous referee that improved the first manuscript.

\section{References}

Clarke R.T., Marker A.F.H. \& Rother J.A. 1987. — The estimation of the mean and variance of algal cell volume from critical measurements. Freshwater Biol., 17 : 117-128.

Hecky R.E. \& Kilham P. 1988. - Nutrient limitation of phytoplankton in freshwater and marine environments : A review of recent evidence on the effects of enrichment. Limnol. Oceanogr., 33 : 796-822.

Lean D.R.S. \& White E. 1983. - Chemical and radiotracer measurements of phosphorus uptake by lake phytoplankton. Can. J. Fish. Aquat. Sci., 40 : 147-155.

Lovstad O. 1984. - Competitive ability of laboratory batch phytoplankton populations at limiting nutrient levels. Oikos, 42:176184.

Lund J.W.G. \& Talling J.F. 1957. — Botanical limnological methods with special reference to algae. Bot. Rev., 23 : 489-583.

Olsen Y. 1989. - Evaluation of competitive ability of Staurastrum luetkemuellerii (Chlorophyceae) and Microcystis aeruginosa (Cyanophyceae) under P limitation. J. Phycol., 25 : 486-499. 
Reynolds C.S. 1984. - The ecology of freshwater phytoplankton. Cambridge University Press, Cambridge : $384 \mathrm{p}$.

Rhee L.A. 1978. - Effects of $N$ :P atomic ratios and nitrate limitation on algal growth, cell composition, and nitrate uptake. Limnol. Oceanogr., $23: 10-25$.

Rhee G.-Y. \& Gotham I.J. 1980. - Optimum N :P ratios and coexistence of planktonic algae. J. Phycol., $16: 486-489$.

Sakshaug E. \& Olsen Y. 1986. - Nutrient status of phytoplankton blooms in Norwegian waters and algal strategies for nutrient competition. Can. J. Fish. Aquat. Sci., 43 : 389-396.

Schindler D.B., Paerl H.W., Keller P.E. \& Lean D.R.S. 1979. - Environmental constraints on Anabaena $\mathrm{N}_{2}$ and $\mathrm{CO}_{2}$-fixation : Effects of hyperoxia and phosphate depletion on the blooms and chemostat cultures. In : Developments in Hydrobiology, Vol. 2 (J. Barica \& Mur L.R., eds.) Dr. W. Junk bv Publishers, the Hague : 221-229.

Shuter B.J. 1978. - Size dependence of phosphorus and nitrogen subsistence quotes in unicellular microorganisms. Limnol. Oceanogr., 28 : 448-465.

Smith R.E.H. \& Kalff J. 1983. --Competition for phosphorus among co-occurring freshwater phytoplankton. Limnol. Oceano$g r ., 28: 448-465$.

Smith V.H. 1983. - Low nitrogen to phosphorus ratios favour dominance by blue-green algae in lake phytoplankton. Science, 221 : 669-671.

Sommer U. 1983. - Nutrient competition between phytoplankton in multispecies chemostat experiments. Arch. Hydrobiol., 96 : 399-416.

Sommer U. 1984. - The paradox of the plankton : Fluctuations of phosphorus availability maintain diversity in flow through cultures. Limnol. Oceanogr., $29: 633-636$.

Sommer U. 1985. - Comparison between steady state and nonsteady state competition. Experiments with natural phytoplankton. Limnol. Oceanogr., $30: 335-346$.

Sommer U. 1993. - Phytoplankton competition in Plußsee : a field test of the resource ratio hypothesis. Limnol. Oceanogr., $38: 838$ 845.
Spijkerman E. \& Coesel P.F.M. 1996. - Competition for phosphorus among planktonic desmid species in continuous-flow culture. J. Phycol., 32 : 939-948.

Stolte W. \& Riegman R. 1996. - A model approach for size-selective competition of marine phytoplankton for fluctuating nitrate and ammonium. J. Phycol., 32 : 732-740.

Suttle C.A., Stockner J.G. \& Harrison P.J. 1987. - Effects of nutrient pulses on community structure and cell size of a freshwater phytoplankton assemblage in culture. Can. J. Fish. Aquat. Sci., 44 : 1768-1774.

Thompson P.A. \& Rhee G.-Y. 1994. - Phytoplankton responses to eutrophication. In : Algae and Water Pollution. (L.C. Rai, J.P. Gaur \& C.J. Soeder eds.) E. Schweizerbart'sche Verlagsbuchhandlung, Stuttgart : 125-166.

Tilman D. 1982. - Resource competition and community structure. Princeton University Press, Princeton : 296 p.

Tilman D. \& Kiesling R. 1984. - Freshwater algal ecology : taxonomic tradeoffs in the temperature dependence of nutrient competitive abilities. In : Current Perspective in Microbial Ecology (M.J. Klug \& C.A. Reddy eds.) Proceedings of the 3rd International Symposium on Microbial Ecology, Amer. Soc. Microbiology, Washington, D.C.: 314-319.

Tilman D., Kiesling R., Sterner R.W., Kilham S.S. \& Johnson, F.A 1986. - Green, blue green and diatom algae : taxonomic differences in competitive ability for phosphorus, silicon and nitrogen Arch. Hydrobiol., 106 : 473-485.

Turpin D.H. 1988.- Physiological mechanism in phytoplankton resource competition. In : Growth and reproductive strategies of freshwater phytoplankton (C. Sandgren ed.) Cambridge University Press, Cambridge : 316-368.

Turpin D.H. \& Harrison P.J. 1980. - Cell size manipulation in natural marine, planktonic diatom communities. Can. J. Fish. Aquat. Sci., $37: 1193-1195$.

Wetzel R.G. \& Likens G.E. 1979. - Limnological analyses. W.B. Saunders Company, Philadelphia: 357 p. 